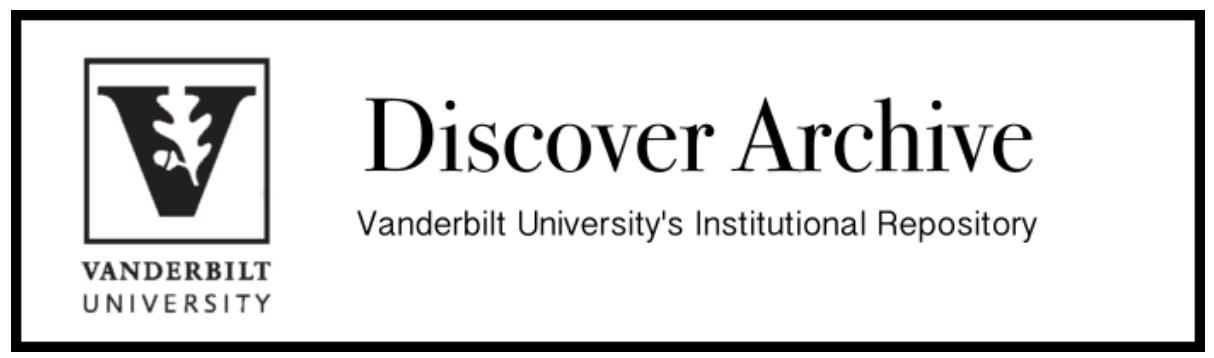




\section{HEINONLINE}

Citation:

Joni Hersch, Increasing Diversity by a New Master's

Degree in Legal Principles, $67 \mathrm{~J}$. Legal Educ. 86

(2017)

Provided by:

Vanderbilt University Law School

Content downloaded/printed from HeinOnline

Mon Jun 11 10:46:58 2018

-- Your use of this HeinOnline PDF indicates your acceptance of HeinOnline's Terms and Conditions of the license agreement available at https://heinonline.org/HOL/License

-- The search text of this PDF is generated from uncorrected OCR text.

-- To obtain permission to use this article beyond the scope of your HeinOnline license, please use:

\section{Copyright Information}

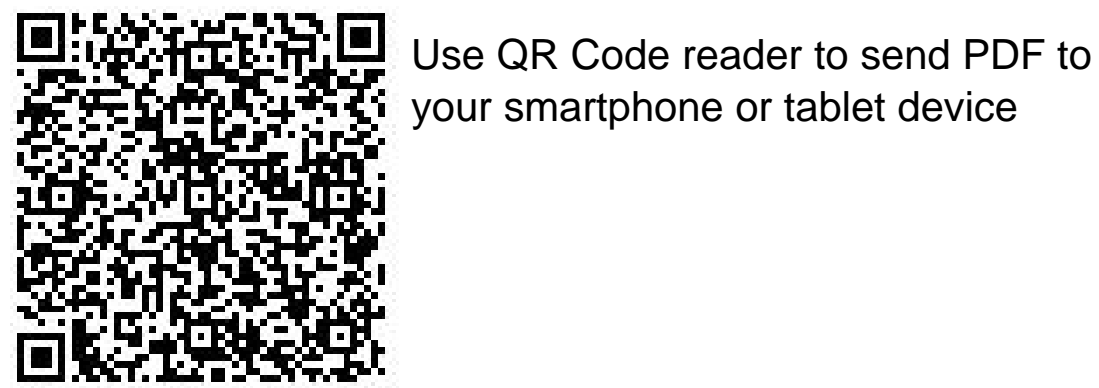




\title{
Increasing Diversity by a New Master's Degree in Legal Principles
}

\author{
Joni Hersch
}

Students who leave their J.D. program before graduation leave emptyhanded, without an additional degree or other credential indicating that their law school studies had any professional, educational, or marketable value. The absence of such a credential combines with the substantial risks and costs associated with law school education to discourage risk-averse students from applying. The adverse impacts of these risks may be especially great for lower-income students who have fewer financial resources to draw on and less information about their fit with legal education and the legal profession. I propose that law schools award a master's degree to students who successfully complete the ${ }_{\mathrm{IL}}$ curriculum but leave before completing the full J.D. curriculum. My suggested name for this degree is master of legal principles (M.L.P.). This degree option would lower the risks associated with law school enrollment as well as provide a valuable and largely standardized employment credential. Using detailed educational data from the National Survey of College Graduates (NSCG), I show that the lack of field-specific training provided by undergraduate majors impedes learning about the likely fit of potential students with the law school curriculum and the legal profession. Using labor market data from the U.S. Department of Labor's Occupational Information Network $\left(\mathrm{O}^{*} \mathrm{NET}\right)$, I document a wide range of occupations for which the M.L.P. degree would be appropriate, in that these occupations draw on legal knowledge but do not require a J.D. degree. Without the debt associated with the full J.D. curriculum, those with the M.L.P. would be positioned to provide limited legal services at a lower cost, thus increasing access to justice. The expanded degree offering of an M.L.P. degree also would benefit law schools by attracting more, and more diverse, applicants.

Joni Hersch is the Cornelius Vanderbilt Professor of Law and Economics at Vanderbilt Law School, I31 21st Avenue South, Nashville, Tenn. 37203. joni.hersch@ vanderbilt.edu. (615) 343-7717. She offers many thanks to Christopher Serkin, Jennifer Bennett Shinall, and W. Kip Viscusi for helpful feedback, and to Sarah B. Dalton and Erin Meyers for outstanding research support. 


\section{Introduction}

The legal profession faces numerous challenges, including concerns over diversity and inclusiveness' and its limited success at providing meaningful access to justice for low-income people. ${ }^{2}$ These factors are, of course, intertwined. To create a diverse student body, law schools would need to enroll more students from racial and ethnic minority groups. ${ }^{3}$ Yet the legal profession has not been successful in fully achieving diversity and inclusivity. ${ }^{4}$ And law students graduate with high debt loads, ${ }^{5}$ and high debt loads make public-service legal careers less attractive, as well as less viable. ${ }^{6}$

The recent downturn in the legal sector and the continuing failure to create a more diverse profession and expand access to justice has led to much debate and examination of the state of legal education. The American Bar Association (ABA) issued the final report of its Task Force on the Future of Legal

1. Am. Bar Ass'n, Diversity \& Inclusion 360 Commission: Executive Summary 4 (20i6), http://www.americanbar.org/content/dam/aba/administrative/diversity-portal/diversityinclusion-exec-summ-36o-comm.authcheckdam.pdf [https://perma.cc/Z2XS-6U8H] [hereinafter ABA Diversity \& INCLUSION] (stating that "[t]he legal profession is one of the least diverse professions in the nation").

2. Dan Lear, Laweyers Need to Move Beyond "Access to Justice" to Close the Legal Services Gap, A. B.A. J.: LEGAL REBEL. (Sept. I, 20I5, 8:30 AM), http://www.abajournal.com/legalrebels/article/lawyers_ need_to_move_beyond_access_to_justice_to_close_the_legal_services_g/ [https:// perma.cc/9JV2-WV7U]; Legal Servs. Corp., Documenting the Justice Gap in America: The Current Unmet Civil Legal Needs of Low-Income Americans 20 (20og), http:// www.americanbar.org/content $/ \mathrm{dam} / \mathrm{aba} / \mathrm{migrated} / \mathrm{marketresearch} / \mathrm{PublicDocuments}$ / JusticeGaInAmerica2oog.authcheckdam.pdf [https://perma.cc/ $\mathrm{MCZ}_{5-5} \mathrm{UMK}$ ].

3. William D. Henderson, Solving the Legal Profession's Diversity Problem, PD Q. (Feb. 2016) 23, https://ssrn.com/abstract=2742436.

4. ABA Diversity \& InCLUSION, supra note I.

5. Task Force on the Fin. of Legal Educ., Am. Bar Ass'n, 2015 Report of the Aba Task Force ON FinANCING LEGAL EDUCATION $3^{-} 3^{2}$ (20I5), http://www.americanbar.org/content/

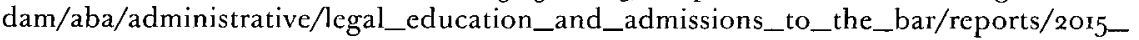
june_report_of_the_aba_task_force_on_the_financing_of_legal_education. authcheckdam.pdf [https://perma.cc/4 YJT-AWNY]. Gita Z. WILDER, NAT'L Ass'N fOR L. Placement, Law School Debt Among New Lawyers: An After the JD Monograph 8 (2007), http://www.americanbarfoundation.org/uploads/cms/documents/ajd_debt_ monograph_2007_final.pdf [https://perma.cc/MW3 R-Q4EB] (finding that only sixteen percent of survey respondents graduated law school without debt and that the reported amounts of debt averaged about $\$ 70,000$ ).

6. Equal Justice Works, NalP \& P'ship for Pub. Serv., From Paper Chase to Money Chase: Law School Debt Diverts Road to Public Service ig (2002), http://www. americanbar.org/content/dam/aba/migrated/marketresearch/PublicDocuments/ Irapsurvey.authcheckdam.pdf [https://perma.cc/SM $4 \mathrm{~A}-5 \mathrm{VUN}]$ (finding that sixty-six percent of graduating law students reported that debt prevented them from considering a public-service career). Public-service legal jobs have also become more competitive, in part because the Public Service Loan Forgiveness Program makes such jobs attractive, and in part because of the tighter private-sector job market for lawyers. See Public Service Loan Forgiveness, FED. STudent AId (20I6), https://studentaid.ed.gov/sa/repay-loans/forgivenesscancellation/public-service [https://perma.cc/M9YT-8AP4]. 
Education in January 2014. ${ }^{7}$ The task force recommends, first, restructuring the financial model of law schools, which discounts tuition for the highestcredentialed students without regard to financial need, while sustaining their budgets through higher tuition paid by students with weaker credentials, noting that "the current system tends to impede the growth of diversity in legal education and in the profession." Second, it recommends revising the accreditation structure to allow for more heterogeneity in law schools and more experimentation and innovation. ${ }^{9}$ Third, it recommends expanding access to justice by "consider[ing] for adoption new or improved frameworks for licensing or otherwise authorizing providers of legal and related services. This should include authorizing bar admission for people whose preparation may be other than the traditional four-years of college plus three-years of classroom-based law school education, and licensing persons other than holders of a J.D. to deliver limited legal services."

With some exceptions that vary by state," a J.D. from a law school accredited by the $\mathrm{ABA}$ is required to take a state's bar examination, and bar examination passage is a requirement to become licensed as a lawyer. The J.D. curriculum typically takes three years. ${ }^{12}$ Legal academics have considerable debate about whether a third year of law school is necessary to train lawyers. ${ }^{13}$

7. See Task Forceonthe Futureof Legal Educ., Am. BarAss', Re Rortand Recommendations (2014), http://www.americanbar.org/content/dam/aba/administrative/professional_ responsibility/report_and_recommendations_of_aba_task_force.authcheckdam.pdf [https://perma.cc/2HBF-JFWD] [hereinafter REPORT \& RECOMMENDATIONS].

8. Id. at 2.

9. Id. (encouraging the ABA to "energetically restructure the variance system as an avenue to foster experimentation by law schools and open the variance process and results to full public view").

Io. Id. at 3 .

ii. See Nat'l Conf. of Bar Exam'rs \& Sec. of Legal Educ. \& Admissions to the Bar, Am. Bar Ass'n Comprehensive Guide to Bar Admission Requirements 20I5 8-9 (2015), http://www.americanbar.org/content/dam/aba/publications/misc/legal_education/2015_ comprehensive_guide_to_bar_admission_requirements.authcheckdam.pdf [https:// perma.cc/ $\left./ 7 \mathrm{~F}_{5} 6-\mathrm{V}_{4} \mathrm{EU}\right]$ (listing Alabama, California, Massachusetts, Tennessee, and Washington as states that allow graduates of non-ABA-approved in-state law schools to take their state's bar exam).

i2. Edward M. Stern \& Gerald L. Wilson, The Napla/SAPLA Book of Law School Lists: INFORMATION ON ABA-ApPROVED LAW SCHOOLS 32-35 (rev. ed. 2015), https://www. bu.edu/cas/files/2015/07/2015-2016-NAPLASAPLA-Book-of-Lists.pdf [https://perma.cc/ $\mathrm{LM}_{5} \mathrm{X}-\mathrm{Z}_{6} \mathrm{~B}_{2}$ ] (listing seventy-three law schools that offer an accelerated J.D. program or accelerated J.D./MBA dual program).

13. See Stanford Law's Larry Kramer on the Law School Revolution, BIG THINк, http://bigthink.com/ the-voice-of-big-think/stanford-laws-larry-kramer-on-the-law-school-revolution [https:// perma.cc/ $/ \mathrm{SJ}_{3} \mathrm{H} \cdot \mathrm{AP}_{3} 8$ ] (quoting Dean Larry Kramer of Stanford Law School: "One of the well-known facts about law school is it never took three years to do what we were doing; "it took maybe two years at most, maybe a year-and-a-half."). See also BRIAN Z. TAMANAHA, FAILING LAW SCHOOLS 20-27 (2012) (summarizing the history that led to a three-year law school requirement and the ongoing debate within the legal academy over the third-year 
Despite arguments that the full J.D. curriculum adds little value, students who leave their J.D. program before graduation leave empty-handed-with no additional degree or other credential that indicates that their law school time had any professional, educational, or marketable value. And, as I show using data from the NSCG, law school graduates emerge from a wide range of undergraduate majors. For this reason, law students have little field-specific preparation upon entering and accordingly limited awareness of the reality of law school. Yet, despite no specific educational background required to enter law school, overall attrition is very low at $19.21 \%$ overall, and it is especially low at the highest-ranked law schools. ${ }^{14}$ Furthermore, the lack of field-specific background leads to an overreliance on LSAT scores in making admissions decisions, ${ }^{15}$ which likewise limits student diversity. ${ }^{16}$

While it may seem a virtue of law schools that attrition is low, I argue that the opposite is the case: Law school attrition is too low, for several reasons examined in this article. In combination, these reasons limit the potential

requirement); Samuel Estreicher, The Roosevelt-Cardozo Way: The Case for Bar Eligibility After Two Years of Law School, I5 N.Y.U. J. Legrs. \& PUB. PoL'Y 599 (2012). Instead of reducing the duration of legal education, the 2007 Carnegie Foundation report on legal education (commonly referred to as the Carnegie Report) recommends greater integration of clinical and professional practice training, along the lines of clinical practice that is a core component of medical education. William M. Sulluvan, Anne Colby, Judith Welch Wegner, Lloyd Bond \& Lee S. Shulman, Carnegie Found. for the Advancement of Teaching, Educating Lawyers: Preparation for the Profession of LaW 192-93 (2007) [hereinafter CARNEGIE REPORT]. Arguments for including more practical professional training within the current three-year law school curriculum are summarized in Adam Chodorow \& Philip Hackney, Postgraduate Legal Training: The Case for Tax-Exempt Programs, 65 J. Legal Educ. ${ }_{4} 6_{3}$, 466-7I (2016).

I4. For example, attrition at the law schools ranked in the top ten by U.S. News \& World Report ranges from no attrition (Harvard, Stanford, Pennsylvania, and Michigan) to $3.7 \%$ (University of California Berkeley). For current law school rankings, see Best Law Schools, U.S. NEWS \& WORLD REP. (20I6), http://grad-schools.usnews.rankingsandreviews.com/ best-graduate-schools/top-law-schools/law-rankings?int=aIdıo8 [https://perma.cc/LgCLTDQH (2016 rankings)]; for attrition rates and other data from all ABA-approved law schools, see ABA Required Disclosures: Standard 509 Information Reports, Am. Bar Ass'n Sec. of Legal Educ. and Admissions to the Bar (2016), http://www.abarequireddisclosures. org (select "Generate Report" under "Compilation-All School Data" with "2or6" as the selected year and "J.D. Attrition (prior academic year)" as the selected section) [https:// perma.cc/8TQ3-BTLP].

I5. See TAMANAHA, supra note 13 , at 85 (claiming that the LSAT is the most important factor of consideration in admissions because the test is "the only uniform measure of the quality of students (grades are unreliable comparators owing to varying degrecs of grade inflation among majors and colleges)").

16. On average, racial and ethnic minorities score below white test-takers on the LSAT. SUSAN P. Dalessandro, Lisa C. Anthony \& Lynda M. Reese, Law Sch. Admission Council, LSAT Technical Report i4-02, LSAT Performance with Regional, Gender, and Racial/ ETHNIC BREAKDOWNS: 2007-2008 THROUGH 20I3-20I4 TESTING YeARS 2, 2I-27 (20I5), http:// www.lsac.org/docs/default-source/research-(lsac-resources)/tr-I4-02.pdf [https://perma.cc/ $\left.\mathrm{DLW}_{3}-\mathrm{B}_{42} \mathrm{~L}\right]$. 
applicant pool, reduce law student diversity, and contribute to an access-tojustice gap.

My main recommendation is that law schools award a master's degree to students who successfully complete the full standard IL curriculum but choose to leave before completing the full J.D. curriculum. My suggested name for this master's degree is master of legal principles (M.L.P.). In addition to the LL.M. degree, which requires completion of a first degree in law, many law schools offer terminal master's degrees for nonlawyers, usually in specified areas. ${ }^{{ }^{7} 7}$ However, because these degrees are not standardized, the various master's programs differ widely from one another, and they are distinctly different from the J.D. program in both admittance criteria and curriculum. In contrast to master's degrees in law currently offered, my proposed M.L.P. would provide a reasonably standardized credential, because all students earning the M.L.P. would have successfully completed the largely standardized $\mathrm{IL}$ year. ${ }^{18}$

My proposal provides the following advantages to legal education and to students. Applications and diversity of applying students would increase, as the option of a master's degree would lower the cost to risk-averse candidates who are unsure of their fit, and law schools would benefit from the opportunity to consider a more diverse applicant pool.

The costs to law schools would be low. Law schools would not have to develop or offer additional courses, as all students would take the same $\mathrm{rL}$ curriculum. Individual universities would need to approve awarding a new graduate degree, but the role of the ABA would not be one of accreditation, as the $A B A$ is authorized to accredit only J.D. programs. ${ }^{19}$ Indeed, the task force recommends that the accreditation system should seek to facilitate innovation and foster experimentation; $;^{20}$ allowing for a master's degree option is precisely in the spirit of innovation and experimentation.

I7. Terminal master's degree programs in law for nonlawyers and LL.M. programs are described in Section III. B. As this section discusses, the curriculum and requirements for these degree programs vary widely, and neither type of degree provides a standardized credential.

I8. See CARnegie Report, supra note i3, at 186 (describing the standardization of the $\mathrm{IL}$ year as follows: “[L]egal pedagogy is remarkably uniform across variations in schools and student bodies. Excepting a few schools, the first-year curriculum is similarly standardized, as is the system of competitive grading that accompanies the teaching and learning practices associated with case dialogue. The consequence is a striking conformity in outlook and habits of thought among law school graduates.").

i9. See Section of Legal Educ. \& Admissions to the Bar, Am. Bar Ass'n, ABA Standards and Rules of Procedure for Approval of Law Schools 23 (2016), https://www.americanbar. $\mathrm{org} /$ content/dam/aba/publications/misc/legal_education/Standards/20I6_20I7_aba_ standards_and_rules_of_procedure.authcheckdam.pdf [https://perma.cc/8P8B-JEAQ] [hereinafter ABA STANDARDS FOR APPROVAL] (According to Standard 3iz(a)-(c), a law school may create a degree program other than a J.D. only if "(a) the law school is fully approved; (b) the Council has granted acquiescence in the program; and (c) the degree program will not interfere with the ability of the law school to operate in compliance with the Standards and to carry out its program of legal education."). 
The benefits to students would be substantial. Students who realize that they do not want to continue to the J.D. would earn a master's degree that signals specialized legal training without incurring three years of debt. Their master's degree generally would not allow them to practice law, but limited licensing is an option at the discretion of states. ${ }^{21}$ If limited licensing were available, the lower debt would enable these master's degree holders to offer legal services for lower compensation, thereby expanding access to justice.

Even if their degree were not used directly in the practice of law, data from the U.S. Bureau of Labor Statistics Occupational Information Network (O*NET) reveal a number of occupations in which legal knowledge is required or valuable. And, even if legal knowledge is not required or utilized for a specific occupation, pay scales in many workplaces are based on a combination of education and work experience, with a master's degree substituting for years of experience, ${ }^{22}$ and candidates with master's degrees are increasingly sought by employers. ${ }^{23}$ Furthermore, society as a whole benefits from a population that is knowledgeable about law. ${ }^{24}$

I begin in Section II by describing the role of incomplete information in the education matching process. In this section, I also present data from the NSCG that show wide variation in undergraduate majors among law students, with most majors providing little or no information about a student's potential fit with law school and the legal profession. Section III discusses the dramatic rise in the master's degree as a professional credential and describes the structure of existing master's programs in law. Section IV discusses how the M.L.P. option would allow for greater experimentation and student diversity while providing a valuable professional credential. Using government data, Section $\mathrm{V}$ documents a wide range of occupations in which legal knowledge is valuable but a J.D. is not required. Section VI discusses current initiatives by states to allow limited legal licensing. Section VII concludes.

2I. As discussed in Section VI, limited legal licensing is available in Washington state and is under consideration in other states.

22. See, e.g., General Schedule Qualification Standards, U.S. Off. OF Personnel MGmT., https://www. opm.gov/policy-data-oversight/classification-qualifications/general-schedule-qualificationstandards (click on the "Group Standard" tab) (last visited Aug. 22, 20I6) (U.S. Federal Government General Schedule (GS) pay scale allows substitution of education and experience: "Education and experience may be combined for all grade levels for which both education and experience are acceptable.").

23. Sean Gallagher, Yes, Master's: A Graduate Degree's Moment in the Age of Higher Education Innovation, New Eng. J. Higher Educ. (Aug. 5, 2014), http://www.nebhe.org/thejournal/yes-mastersa-graduate-degrees-moment-in-the-age-of-higher-education-innovation/ [https://perma.cc/ QNJ9-3DNA].

24. Dean's Steering Comm., Ass'n Am. L. Sch., Statement on the Value of a Legal Education (2015), http://www.aals.org/wp-content/uploads/20I4/og/Statement-on-the-Value-of-a-LegalEducation.pdf [https://perma.cc/ 55 YYYTH8]. 


\section{Incomplete Information in the Educational Matching Process}

\section{A. The Educational Matching Process}

Because undergraduate grades, standardized tests scores, and letters of recommendation weigh heavily in the admissions decision, students who enter graduate programs are by definition those who were successful as undergraduates. But the undergraduate experience rarely provides adequate information about the reality of graduate education. Applying to graduate programs is very much like applying for jobs. Candidates for jobs and for graduate degree programs submit applications that include academic credentials, work experience, and letters of recommendation, and often undergo in-person interviews. Both sides of the market seek to make successful matches in which productivity will be high and turnover low.

Although both sides strive to acquire sufficient information about the probability of a successful match, this does not always happen for jobs, academic programs, or, for that matter, marriages. In the employment sphere, it is understood that jobs are "experience goods," and that workers continue to learn about the characteristics of the job, and their match with their job, during the course of their employment. ${ }^{25}$ Not all matches are successful, and unsuccessful employment relations will end and workers will move to betterquality job matches. ${ }^{26}$ Furthermore, graduate school provides a mechanism to productively wait out economic downturns by investing in education. ${ }^{27}$ Those students who were at the margin of attending graduate school are also the ones who will be less sure of their fit with their graduate program, although admissions committees can do little to identify those students. ${ }^{28}$

Consider now the contrast between graduate and undergraduate programs. Although undergraduate students sometimes are required to declare a major and apply to specific programs when they apply to a college, changing majors is extremely common. Students respond to new information regarding

25. See W. Kip Viscusi, Job Hazards and Worker Quit Rates: An Analysis of Adaptive Worker Behavior, 20 INT'L ECON. REv. 29 (I979) (showing that workers leave jobs when they discover that their workplace has a higher injury risk than they anticipated at the time they accepted the job).

26. See, e.g., Joni Hersch, Optimal "Mismatch" and Promotions, 33 Econ. InQuiry 6ri (I995); Boyan Jovanovic, Job Matching and the Theory of Tumover, 87 J. POL. Econ. 972 (1979).

27. See, e.g., Clifton B. Parker, The Great Recession Spurred Student Interest in Higher Education, Stanford Expert Says, Stan. U. News (Mar. 6, 2015), http://news.stanford.edu/2015/o3/o6/higher-edhoxby-030615/ [https://perma.cc/8FR9-3ZDA] (quoting an interview with Caroline Hoxby in which she states that "people who would have taken some time off between undergraduate and graduate school decide to go straight to graduate school"). See also Tamanaha, supra note 13 , at ${ }_{13} 6$ ("Law school has traditionally been thought of as a safe harbor in a poor economy.").

28. TAMANAHA, supra note 13 , at $135^{-} 3^{6}$ (describing two types of students who enter law school: students who had been on the path to law school all along and those who were never entirely committed but find themselves dissatisfied with other career options; also noting that these two types are not obviously distinguishable, and that students change their degree of commitment while in law school). 
educational match as they learn about their interests and strengths through field-specific classes. Studies show that about one-third of those declaring a major in the fields of science, technology, engineering, and math (STEM) change major at least once. ${ }^{29}$ Studies from individual universities not restricted to STEM majors show that an even higher share of students change majors. For example, sixty-one percent of University of Florida students change their major by the end of their second year. $3^{\circ}$ In a survey of undergraduate students at a large northeastern business school, only fifty-two percent had not changed their major at all..$^{11}$

In contrast, graduate students are locked into specific programs. For the most part, students who apply to graduate programs will have considerable field-specific experience in their major. Those who apply to medical schools typically major in a science such as biology (and those who don't major in sciences take a set of science classes to prepare them for the MCAT), those who enter graduate programs in engineering typically majored in engineering, and so forth. In contrast, no field-specific undergraduate major is required or even expected for law school admissions. Furthermore, in the U.S. (in contrast to the educational system in many other countries),,$^{32}$ few universities offer undergraduate majors in law or legal studies. 33 Of course, admissions committees seek evidence that a student has the requisite analytical and writing skills, but these skills can be signaled by many different college majors.

Even after taking into account the selection process that favors students with majors associated with law school success, the consequence of having no fieldspecific requirements for admission results in a wide range of undergraduate majors among law students, as I show in Table I below. Students therefore have little opportunity as undergraduates to assess their fit with the law school curriculum. And, in contrast to undergraduate programs generally allowing for

29. See Xianglei Chen \& Matthew Soldner, Nat'l Ctr. Educ. Stat., Stem Attrition: College Students' Paths into and out of STEM Fields 14 (2013), http://nces.ed.gov/ pubs20I4/20I40orrev.pdf [https://perma.cc/DE5G-JGLN] (showing the following shares that change majors: twenty-eight percent of students beginning with a STEM major, fortytwo percent of students beginning with an education major, and thirty-five percent of students beginning with a health sciences major).

3o. Exploratory, C. OF Liberal ArTs \& SCI., U. Fla. (20I6), https://www.advising.ufl.edu/ exploratory/ [https://perma.cc/L9QC-H6 $\left.{ }_{5} \mathrm{~S}\right]$.

3. Charles A. Malgwi, Martha A. Howe \& Priscilla A. Burnaby, Influences on Students' Choice of College Major, 8o J. Educ. Bus. 275, 278 (2005).

32. TAMANAHA, supra note 13 , at 173 ("A law degree is an undergraduate degree in most countries.").

33. See Big Future: College Search, C. BOARD, https://bigfuture.collegeboard.org/college-search (last visited Aug. 17, 2017) (Out of 3715 colleges, the following search criteria filters show that among four-year colleges or universities, 142 offer legal studies as a major and 225 offer prelaw programs: Select "4-year college or university" under the "Type of School" tab and then under the "Majors \& Learning Environment" tab, enter "Legal Studies, General" and "Pre-Law Studies" in the "Select a specific major" search box.). 
mobility among majors, ${ }^{34}$ once in law school, students are not only locked into the specific degree, but are locked into a highly standardized degree program with very limited opportunities to pursue broader interests. Therefore, given students' limited knowledge about their fit with the law school curriculum and lack of curricular flexibility, the real surprise is that law school attrition is so low.

\section{B. J.D. Attrition vs. Ph.D. Attrition}

Even though Ph.D. students typically enter their programs with fieldspecific backgrounds, attrition in Ph.D. programs is much higher than in most J.D. programs. Admission to top $\mathrm{Ph} . \mathrm{D}$. programs is highly competitive, and top Ph.D. programs, like top law schools, are highly selective in admissions ${ }^{35}$ and admit only those students who are expected to successfully complete their degree. $3^{6}$ Yet attrition in Ph.D. programs is about fifty percent, ${ }^{37}$ which is well above the attrition rate of $19.21 \%$ for law schools overall, and on par with the highest attrition rates reported by any law school. $3^{8} \mathrm{Ph} . \mathrm{D}$. programs have high attrition even though admission is highly selective and the programs admit students with field-specific background who are informed about their likely match with their graduate degree program.

34. Changing majors may lead to a longer time in college but is usually feasible. See Major Dilemma: The Truth About Sreitching Majors, USA Today C. (Aug. 28, 20II, 3:13 PM), http:// college.usatoday.com/2011/o8/28/major-dilemma-the-truth-about-switching-majors/ [https://perma.cc/F 7 FG-XX29].

35. See Jeff Allum \& Hironao Okahana, Council of Graduate Sch., Graduate Enrollment AND Degrees: 2004 TO 2014, at 3, 9 (2015), http://cgsnet.org/ckfinder/userfiles/files/E_ and_D_2or4_report_final.pdf [https://perma.cc/Hg2K-ZTEN] (finding that among the $6{ }_{3} 6$ universities that reported information to the annual CGS/GRE Survey of Graduate Enrollment and Degrees, the Fall 20I4 Ph.D. program acceptance rate was 21.9\% overall, with the rate lower at very high-research-activity universities).

36. Julie R. Posselt, Toward Inclusive Excellence in Graduate Education: Constructing Merit and Diversity in PhD Admissions, I20 AM. J. EDUC. 48I, 495 (2014) (stating that admissions committees at highly ranked $\mathrm{Ph} . \mathrm{D}$. programs express great risk aversion and rely strongly on high GRE scores and grades to minimize the risk of admitting applicants who they fear would waste faculty members' time).

37. Barbara E. Lovitts \& Cary Nelson, The Hidden Crisis in Graduate Education: Attrition from Ph.D. Programs, ACADEmE, Nov.-Dec. 2000, at 44, 45 (2000) ("Although comprehensive national data do not exist on the consequences of graduate students' abandoning their degree programs, forty years of studies suggest the long-term attrition rate nationwide is about $5^{\circ}$ percent."); Lynn McAlpine \& Judith Norton, Reframing Our Approach to Doctoral Programs: An Integrative Framework for Action and Research, 25 Higher Educ. REs. \& DEv. 3, 3 (2006) (reporting that doctoral attrition rates average from thirty percent to fifty percent, depending on the field); Scott Smallwood, Doctor Dropout, Chron. Higher Educ., Jan. i6, 2004, at Aio (stating that "the attrition rate for Ph.D. programs is 40 percent to 50 percent"). See also Ph.D. Completion Project, Council of Graduate Sch. (2008), http://cgsnet.org/phd-completionproject-o [https://perma.cc/58PN-LHL6].

38. The highest attrition rates in the Standard 509 Information Reports are for Charlotte School of Law (49.2\%) and Thomas Jefferson School of Law (47.0\%). ABA Required Disclosures, supra note 14 . 
But a student who starts but does not complete a Ph.D. program has an important advantage over law students. Those who do not complete their Ph.D. but successfully complete core requirements of their Ph.D. curriculum can be awarded a master's degree. ${ }^{39}$ In contrast, under the current law school structure, law students who do not complete their J.D. degree leave law school without any additional academic credential.

\section{Diversity of Undergraduate Background of Potential Law Students Impedes Learning About Fit}

To provide information on the wide diversity of college majors for those with a J.D., I use data from the National Survey of College Graduates 2010 and ${ }_{2013}$ (NSCG). $4^{\circ}$ The NSCG is one of the surveys included in the Scientists and Engineering Statistical Data System (SESTAT) sponsored by the National Science Foundation. These surveys are nationally representative of college graduates residing in the United States and provide unusually detailed information on education, labor market characteristics, and demographics. ${ }^{4}$ The number of observations is 77,188 for the 2010 survey and 104,599 for the 2013 survey. $4^{2}$

NSCG respondents report detailed information on their first bachelor's degree and two most recent degrees (other than first bachelor's degree) at the bachelor's level or higher. For each degree reported, respondents provide the year the degree was obtained, the type of degree (bachelor's, master's, doctorate, or professional), and the field of study (selecting from a list of more than 140 narrowly defined fields). I group undergraduate majors into

39. A master's degree can usually be awarded after completion of core $\mathrm{Ph}$. D. requirements, with requirements set by the university. See, e.g., Master's Requirements, Brown U. Graduate Sch. (2016), https://www.brown.edu/academics/gradschool/masters-programs [https://perma. $\mathrm{cc} / \mathrm{N}_{7} \mathrm{NF}-\mathrm{DZG}_{3}$ ] (last visited Aug. 22, 20I6) (At Brown University, the graduate school awards master's degrees "in the listed programs as terminal degrees or during ordinary progress toward a Ph.D. The minimum requirements for a master's degree are admission to the program and, typically, eight graduate-level courses, successfully completed.").

40. Data from the NSCG surveys are used in a number of articles published in the economics literature. See, e.g., Joni Hersch, Opting Out Among Women with Elite Education, II REv. Econ. HousEHOLD 469 (2013); Jennifer Hunt, Which Immigrants Are Most Innovative and Entrepreneurial? Distinctions by Entry Visa, 29 J. LAB. ECON. 4I7 (2OII).

4I. For more information on SESTAT and to download data, see SESTAT, NAT'L SCI. FOUND., http://www.nsf.gov/statistics/sestat/ (last updated May 2I, 20I5) [https://perma.cc/9NAX$\left.{ }_{5} \mathrm{PBX}\right]$. The NSCG is a stratified random sample of individuals who, as of the survey reference dates (Oct. I, 2010 and Feb. I, 2013), were less than $7^{6}$ years old, not institutionalized, living in the United States or in a U.S. territory, and had earned a bachelor's degree or higher in any field. The surveys oversample groups of special interest to the SESTAT program (e.g., those in science and engineering fields and minorities). I take into account the sample design using the provided probability weights so that the values reported in Table I are representative of the entire college-educated population.

42. No first bachelor's degree information is available for $6 \mathrm{r}_{4} 6$ individuals, and these observations are excluded from the statistics shown in Table $\mathrm{I}$. This leaves the sample of ${ }_{75}, 64 \mathrm{I}$ shown in the first column of values in Table $\mathrm{I}$. 
seventeen categories indicated in Table I. I identify graduate and professional degrees using information on highest type of degree earned combined with field of study of highest degree.

\begin{tabular}{|c|c|c|c|c|}
\hline \multicolumn{5}{|c|}{ Table I: Distribution of Undergraduate Majors } \\
\hline & $\begin{array}{l}\text { All College } \\
\text { Graduates }\end{array}$ & J.D. & $\begin{array}{c}\text { M.A. } \\
\text { Engineering }\end{array}$ & M.D. \\
\hline & (I) & (2) & (3) & (4) \\
\hline English & 2.84 & 6.74 & 0.07 & 1.74 \\
\hline History & $\mathrm{I} .8 \mathrm{I}$ & 8.82 & 0.02 & I.6o \\
\hline Other Arts/Humanities & 9.08 & 10.87 & 0.30 & $2.8 \mathrm{I}$ \\
\hline Economics & 2.28 & 6.34 & 0.35 & I. 20 \\
\hline Business & 20.45 & 12.01 & 0.95 & I.19 \\
\hline Education & II.93 & $0.8 \mathrm{I}$ & $0.9 \mathrm{I}$ & 0.74 \\
\hline Engineering & 8.09 & 2.44 & 86.91 & $2.5 \mathrm{I}$ \\
\hline Math/Computer Science & 4.97 & $\mathrm{I} .79$ & 3.54 & $\mathrm{I} .59$ \\
\hline Biology & 3.28 & I. 40 & 0.72 & 35.84 \\
\hline Chemistry & I. 26 & $0.7 \mathrm{I}$ & I.05 & 7.69 \\
\hline Other Sciences & II. $2 \mathrm{I}$ & 3.15 & $3 \cdot 5^{6}$ & 34.80 \\
\hline Political Science & 3.13 & 23.57 & 0.13 & $0.5^{8}$ \\
\hline Psychology & $5 \cdot 55$ & 5.27 & 0.23 & 4.69 \\
\hline Sociology & $2.7^{8}$ & 3.88 & 0.13 & 0.78 \\
\hline Other Social Sciences & 2.08 & $2.8 \mathrm{I}$ & 0.22 & I. 37 \\
\hline Legal Studies & 0.49 & 4.42 & 0.02 & 0.00 \\
\hline Other Fields & 8.77 & 4.99 & 0.88 & 0.88 \\
\hline Number of Observations & $\mathrm{I} 75,64 \mathrm{I}$ & $4,67 \mathrm{I}$ & 12,032 & 3,088 \\
\hline
\end{tabular}

Table I reports the distribution of undergraduate majors for the full sample in column I, which includes those with highest degree bachelor's as well as with graduate or professional degrees. Column 2 reports the distribution for those with a J.D. For comparison to the undergraduate majors of those with a J.D., I report the distribution for two additional graduate degrees, master's degree in engineering (column 3 ) and professional degree in medicine (column 4). 43 Law and medicine are the two most common professional degrees earned. ${ }^{44}$ Engineering is similar to law in that licensing is required to practice

43. Column 5 is labeled M.D., defined as a professional degree in medicine; the NSCG includes in this category medicine, dentistry, optometry, osteopathy, podiatry, and veterinary.

44. Master's degrees are classified separately from doctorates and professional degrees. Examples of professional degrees identified in the NSCG survey instrument are J.D., LL.B., M.D., D.D.S., and D.V.M. See U.S. Census Bureau \& U.S. Dept. Com., 2013 National Survey of College Graduates, Nat'L SCI. Found. 9 (OMB No. 3145-0I4I, 2013), http://www.nsf.gov/ 
as a professional engineer, 45 and, because engineering is generally a two-year master's degree program, it is closer in duration to a J.D. than medical training, which includes four years of medical school curriculum followed by internship and residency. Each column in Table I reports the percentage of respondents with that undergraduate major among those who have the highest degree reported in the column heading.

Comparing undergraduate majors for all college graduates in column i to undergraduate majors of those who earned a J.D. in column 2 shows that those who earn a J.D. are more likely than all college graduates to major in humanities and liberal arts fields, and less likely to major in business, education, or STEM fields. Most notable is that undergraduate majors vary far more widely among those with J.D.s compared with those with a master's degree in engineering or a professional degree in medicine. The highest concentration of undergraduate majors among those with a J.D. is in political science, with less than a quarter $(23.57 \%)$ of the J.D. holders with an undergraduate major in that field. The second most common major is business, with $12.01 \%$ majoring in that field. Only $4.42 \%$ majored in legal studies. Because these grouped fields combine several other majors, the undergraduate majors are even more dispersed than indicated by Table I. In contrast, $86.91 \%$ of those with master's degrees in engineering were undergraduate engineering majors, and $78.33 \%$ of those with medical degrees majored in either biology, chemistry, or another science. The distribution of undergraduate majors for other graduate degree holders is not reported in Table I, but similarly shows that most graduate degree holders majored as undergraduates in fields highly related to their graduate degree field.

The data reported in Table I are based on those who actually earned the degree indicated in the column heading. A student who started but did not complete a graduate degree program would appear in the full sample results of column r only. The wide variation in undergraduate majors among those with a J.D. suggests that even those who successfully earned their J.D. had little field-specific background when they entered law school, and therefore only limited information about their potential fit. With the exception of those in law school, students with better field-specific preparation will be more likely to be admitted to graduate programs, as admissions committees consider their likelihood of successfully earning their degree to be higher. Because law schools are required to report attrition, but undergraduate major of applicants is highly variable and not field-specific, the incentive of law schools is to reduce risk by relying more heavily on signals such as the LSAT, as information on

statistics/srvygrads/surveys/srvygrads-newrespond20r3.pdf [https://perma.cc/6 $\mathrm{M}_{7} \mathrm{Z}$ $\left.\mathrm{K}_{2} \mathrm{P}_{3}\right]$. Calculations using the NSCG show that among those with professional degrees, $42.4 \%$ are in medicine and $49.8 \%$ are in law.

45. See What Is a PE?, NAT'L SOC'Y PROF. ENGINEERs, https://www.nspe.org/resources/licensure/ what-pe [https://perma.cc/LN2G-QNDG] (last visited Aug. 22, 2016) ("Now every state regulates the practice of engineering to ensure public safety by granting only Professional Engineers (PEs) the authority to sign and seal engineering plans and offer their services to the public."). 
undergraduate preparation will be relatively uninformative about the fit and likely law school success.

\section{The Master's Degree as a Professional Credential}

\section{A. The Rise of the Master's Degree}

The number of master's degrees awarded and the range of fields of degrees have increased dramatically. ${ }^{46}$ In fact, the master's degree has been referred to as "the new bachelor's" degree. ${ }^{47}$ Hiring managers report that they use master's degrees to "filter and sort the most promising candidates." ${ }^{8}$ Some occupations require a master's degree for employment, and even when a master's degree is not required, a pay premium often exists relative to a bachelor's degree in the same field. ${ }^{49}$ The increase has been dramatic in the types of professional master's degrees that provide advanced training in science or math combined with business skills. ${ }^{\circ}$ Certainly the decision to pursue a professional master's degree must entail comparison of financial benefits of professional training to the costs, which will be far lower for a one- to two-year master's program than a three-year J.D. program..$^{5}$

Terminal master's degree programs are specifically designed to end after completion of specified requirements, and, for the most part, course work taken for the master's degree does not transfer to $\mathrm{Ph}$.D. program requirements. However, students may enter a Ph.D. program and earn a master's degree along the way, or else leave after earning a master's degree without completing

46. Thomas D. Snyder, Cristobal de Brey \& Sally A. Dillow, Digest of Education Statistics 2015: 5IST EdrTion 639 (2016), https://nces.ed.gov/pubs2or6/2016or4.pdf [https://perma. $\left.\mathrm{cc} / \mathrm{F}_{7} \mathrm{EYYY}_{4} \mathrm{~K} 6\right]$ (reporting in Table 323.10 that the number of master's degrees conferred by postsecondary institutions by field of study from $1970-2013$ has increased from 235,564 in 1970-1971 to 754,475 in 2013-2014).

47. Laura Pappano, The Master's as the Nere Bachelor's, N.Y. TimEs, July 24, 20II, at EDi6.

48. Gallagher, supra note 23 .

49. Elka Torpey \& Dalton Terrell, Should I Get a Master's Degree?, Bureau of Lab. StaT.: Career OUTLOоK (Sept. 2015), http://www.bls.gov/careeroutlook/2015/article/should-i-get-amasters-degree.htm [https://perma.cc/8CUQ-MEKB].

5o. See, e.g., Understanding the Changing Market for Professional Master's Programs: An Introduction for Deans and Other Academic Leaders. Executive Summary, EDuc. Advisory BOARD, https://www.eab.com/ research-and-insights/academic-affairs-forum/studies/2015/understanding-the-changinglandscape-for-professional-masters-programs [https://perma.cc/GQA6-WDAT] (last visited Aug. 22, 2016).

51. Christopher J. Gearon, Focus on Fob Skills with a Professional Master's Degree, U.S. NEws \& WorLD REP. EDuc. (Mar. I3, 2013, 8:30 AM), http://www.usnews.com/education/best-graduateschools/articles/2013/o3/I3/focus-on-job-skills-with-a-professional-masters-degree [https:// perma.cc/ $\left.{ }_{4} \mathrm{UNV} \mathrm{T}_{3} \mathrm{SP}\right]$. 
a Ph.D.; some do this to reduce risk,,$^{52}$ or because a terminal master's program in their desired field is not offered. .53

Students considering law school but deterred by the three-year commitment and expense coupled with uncertainty about their fit with law may recognize that their career objectives might be met by considering other professional programs that are one to two years in duration. Such programs that provide training that would permit similarly attractive professional careers include master of public policy (M.P.P.), master of public administration (M.P.A.), and master of business administration (M.B.A.).

With the exception of the J.D., enrollment in these programs increased dramatically over the period from 1970-1971 to 2013-2014. The number of J.D.s awarded increased over this period by 2.5 times, from $17,44 \mathrm{I}$ to $44,169.54$ In contrast, the number of master's degrees in business has increased by sevenfold, from 26,490 to $189,328.55$ The category of master's degree in public administration and social services, which would include M.P.P. and M.P.A. degrees (which are not reported separately), increased over this period by nearly sixfold, from 7,785 to 44,490 , and now exceeds the number of J.D.s awarded.$^{6}$ The rapid increase in M.B.A., M.P.P., and M.P.A. degrees suggests that professional master's-level training is a valued credential.

\section{B. Structure of Existing Master's Programs in Law}

Many law schools offer LL.M. programs, which is a master's degree program available only to those who hold a first degree in law. ${ }^{57}$ Most LL.M. programs enroll primarily international students, while others provide additional specialized training to lawyers in specific areas..$^{8}$ The LL.M. is not a relevant

52. Chris M. Golde, Should I Stay or Should I Go? Student Descriptions of the Doctoral Attrition Process, 23 Rev. Higher Educ. 199, 2ir (2000) (quoting a student who stated that his decision to pick up a master's degree was a "strategy for dealing with the uncertainty of graduate life in the department").

53. Maresi Nerad \& Debra Sands Miller, Increasing Student Retention in Graduate and Professional Programs, 92 NEw Directions For Inst. Res. 6r, 66 (rg96) (reasoning that some students may enter Ph.D. programs only because the institution does not offer a terminal master's degree in their field or because it is more common for Ph.D. students than master's students to receive funding).

54. SNYDER ET AL., supra note 46 , at $60_{5}$.

55. Id.

56 . Id.

57. See fD or LLM-What's the Difference?, L. SCH. ADMIssion CounciL (2016), http://www.lsac.org/ $1 \mathrm{~mm} /$ degree/J.D.-llm-difference [https://perma.cc/ZMgT-7WLK].

58. For example, Georgetown and New York University offer an LL.M. in taxation for lawyers. Taxation LL.M., GeORGetown LAW (2016), https://www.law.georgetown.edu/academics/ 
alternative to my proposed M.L.P. because a J.D. is required for admission to LL.M. programs.

A number of law schools also offer master's programs in law for nonlawyers. 59 The ABA does not formally approve or accredit any degree program offered by an ABA-approved law school other than the J.D. However, ABA-accredited law schools are not allowed to offer a non-J.D. program without first obtaining acquiescence from the $\mathrm{ABA}$, which requires that the new program is not detrimental to the J.D. program. ${ }^{60}$

A search for non-J.D. master's programs (excluding LL.M. programs) related to legal studies in ABA-approved law schools identified seventy-two programs. ${ }^{6 r}$ Although based in law schools, these programs are structurally different from J.D. programs, do not usually require submission of LSAT scores or otherwise have the same admissions requirements as for J.D. admissions, ${ }^{62}$ and do not have the same curriculum, although in many programs students take some classes offered in the regular J.D. curriculum. Most law schools explicitly prohibit students from transferring credits earned in the master's program to a J.D. program, and few programs allow students to apply previously earned J.D. credits to the master's program. ${ }^{63}$ Tuition per credit-hour is usually the

academic-programs/graduate-programs/degree-programs/taxation/ [https://perma. $\left.\mathrm{cc} / \mathrm{JJZ}_{7} \cdot \mathrm{BF}_{3} \mathrm{C}\right]$. Georgetown and NYU also offer master's programs for nonlawyer tax professionals.

59. For examples of academic master's degrees for nonlawyers, see Post-F.D. and Non-F.D. Programs, AM. BAR Ass'N (2016), http://www.americanbar.org/groups/legal_education/ resources/llm-degrees_post_j_d_non_j_d.html [https://perma.cc/GXX ${ }_{2}-Y_{5} \mathrm{KP}$ ] (listing juris master (J.M.), master of jurisprudence (M.J.), master of science or master of studies (M.S.), master of professional studies (M.P.S.), and master of legal studies (M.L.S.)).

6o. ABA StANDARDS FOr APproval, supra note ig.

6I. This list, which also provides information about the structure and admissions requirements of the master's program, is available on request. To compile this list, the starting point is the ABA list of post-J.D. and non-J.D. programs. See Post-F.D. Non- -.D. Programs by School, AM. BAR Ass'N (2016), http://www.americanbar.org/groups/legal_education/resources/ Ilm-degrees_post_j_d_non_j_d/programs_by_school.html [https://perma.cc/S864$\left.\mathrm{YS}_{4} \mathrm{~A}\right]$. Of this list of ${ }_{175} \mathrm{schools}$, only programs that are not specifically designed for foreign lawyers (LL.M., M.C.L., M.C.J.), are not doctorate level (J.S.D., S.J.D.), and are not certificate programs were investigated. Of the remaining seventy-six schools, further investigation of each individual school's website found that twelve schools that are listed by the ABA as having a relevant master's program do not have such a program. Finally, a search of the following terms yielded eight additional programs: "Master of Legal Studies," "Master of Arts in Legal Studies," "Master of Science in Legal Studies," "Juris Master," "Master of Jurisprudence," "Master of Studies in Law," "Master of Science in Law," and "Master of Arts in Law."

62. Only eighteen of seventy-two programs require an admissions test (and many of these are only for students without enough work experience or a previous graduate degree).

63. At the law schools at Roger Williams University and the University of Pittsburgh, students can apply previously eamed J.D. credits toward their master's degree. However, they can transfer in only up to half of the total required program credits and therefore cannot be 
same as for the regular J.D. program, and most programs would take one year to complete as a full-time student, although a number of these programs allow part-time attendance and online enrollment. ${ }^{6}$

Many of these programs provide specialized knowledge in specific areas or are intended to provide supplemental legal training for those in occupations where legal training is valuable. The programs for nonlawyers are typically focused on specific areas such as tax law (Georgetown, New York University), ${ }_{5}$ preparation for the patent bar exam ${ }^{66}$ (Case Western Reserve, Colorado, Minnesota), ${ }^{67}$ business-centered legal training for STEM professionals (Northwestern), ${ }^{68}$ or as a complement to doctoral studies or for those with doctoral training (Yale, Stanford, Cornell, Chicago). ${ }^{69}$

awarded a master's degree based entirely on completion of only J.D. courses. Master of Studies in Law Degree (MSL)-FAQs, Roger Williams U. Sch. L. (2016), http://law.rwu.edu/ academics/curriculum/msl/faqs [https://perma.cc/53 $\left.\mathrm{R}_{5}-\mathrm{W}_{74} \mathrm{C}\right]$; Master of Studies in Law Frequently Asked Questions, PittLaw (2016), http://law.pitt.edu/academics/non-lawyers/msl/ faq\#haveJ.D. [https://perma.cc/4MAR-8PQV].

64. Twelve programs offer both online and in-person degrees, forty-two offer only in-person degrees, and eighteen offer exclusively online programs.

65. Taxation-Master of Studies in Law (for Non-Lawyer Tax Professionals), Georgetown Law (2016), http://www.law.georgetown.edu/academics/academic-programs/graduate-programs/ online-programs/msl-in-tax.cfm [https://perma.cc/LB $45-\mathrm{Y}_{5} \mathrm{GU}$ ]; The MSL in Taxation, N.Y.U. L. (2016), http://www.law.nyu.edu/msltax [https://perma.cc/SC 4 D-RLY8] ("While the MSL will not prepare or qualify students for the practice of law or to sit for any state bar, CPA exam, or other professional licensure exam, it does provide experienced tax professionals an opportunity to study tax law as it is taught here at NYU Law.").

66. See U.S. Patent \& Trademark Off., General Requirements Bulletin for Admission to the Examination for Registration to Practice in Patent Cases before the United States Patent and Trademark Office 4 (20I5), http://www.uspto.gov/sites/default/ files/OED_GRB.pdf [https://perma.cc/WDY 4 -PVLW] (requiring that a candidate show "requisite scientific and technical training" for admission to the examination, specifically in the fields of engineering, computer science, or a physical or biological science).

67. Masters in Patent Practice, CASE W. Res. U. (2016), http://aw.case.edu/Academics/Degrees/ Masters-in-Patent-Practice [https://perma.cc/ ${ }_{4} \mathrm{H}_{3} \mathrm{R}$-GWYW] (describing a thirty-credit master's degree program with a focus in patent law for students holding an undergraduate degree in engineering or in the computer, physical, or biological sciences); M.S.P.L. Program, U. MINN. (2016), https://www.law.umn.edu/academics/degree-programs/mspl-program [https://perma.cc/X6KN-2YCC] (describing a one-year professional degree program combining classes in patent law and "project-based learning about business strategies and extensive practical hands-on training"); MSL Degree Program, U. CoLo. (2016), http:// www.colorado.edu/law/academics/degrees/msl-degree-program [https://perma.cc/B6 5 U$\mathrm{ZCW}_{7}$ ] (describing a one-year, twenty-eight-credit master's degree program for individuals with undergraduate degrees in engineering and science).

68. Master of Science in Law, Nw. U. (2016), http://www.law.northwestern.edu/academics/degreeprograms/msl/ [https://perma.cc/ $/ \mathrm{Hg}_{9} \mathrm{~F} \cdot \mathrm{V}_{9} \mathrm{RJ}$ ] (describing a one-year program covering legal topics in three main areas: "intellectual property and patent design; business law and entrepreneurship; and regulatory analysis and strategy").

69. M.S.L.Admission-Application Details, Fees \& Schedule, YALE L. SCH. (2016), https://wwwlaw.yale. edu/studying-law-yale/degree-programs/graduate-programs/msl-program/msl-admission [https://perma.cc/ $\mathrm{D}_{2} \mathrm{~W}_{7}$-VPVH] (stating that applicants must "have a doctoral degree or 
As some examples, Yale offers a master of studies in law (M.S.L.), a oneyear terminal degree. Admission to the Yale M.S.L. program does not require submission of test scores, and credits earned in M.S.L. program cannot be transferred to the J.D. program. The Yale program is designed for doctoral candidates, students with a doctoral degree, or working journalists, and, unlike most master in law programs, students in the M.S.L. program take the standard $\mathrm{IL}$ curriculum with J.D. students. $7^{\circ}$ Another similarly structured program designed for current Ph.D. students or postdoctoral fellows is offered at Cornell Law School. ${ }^{\prime}$

\section{Advantages of the Proposed Master of Legal Principles Degree}

\section{A. The M.L.P. Reduces Risk and Would Increase Student Diversity}

As this overview of existing master in law programs indicates, it is not possible for a student who enters but leaves a J.D. program after one year to earn a master's degree. ${ }^{72}$ Three years is a costly commitment to an uncertain outcome. A student who realizes that the fit is bad but leaves after one year will have nothing to show for this year of education. And students are frequently subject to the "sunk cost fallacy," believing that because they have already sunk money into their law school investment, they must continue to invest to complete their degree, even when continuing would not pass a benefit-cost

\footnotetext{
be a doctoral candidate in a field other than law, unless the applicant is a working journalist (journalists must have at least a bachelor's degree)"); Advanced Degree Programs, STAN. L. Sch. (2016), https://law.stanford.edu/education/degrees/advanced-degree-programs/ [https:// perma.cc/ET 5 S-KUGA] ("The Master of Legal Studies (MLS) is a nonprofessional degree designed for advanced graduate students from the United States or abroad who have no prior legal training."); Cornell Law School: Degrees, Cornell L. SCH. (2016), http://www. lawschool.cornell.edu/international/degrees.cfm [https://perma.cc/4 $\mathrm{HG}_{7}$-SMCW] ("The M.S.L.S. is a one-year nonprofessional degree intended for Cornell University graduate Ph.D. students and post-doctoral fellows who have no prior legal training.").
}

70. M.S.L.Degree Program Requirements, YALE L. SCH. (2016), https://www.law.yale.edu/studying-lawyale/degree-programs/graduate-programs/msl-program/msl-degree-program-requirements [https://perma.cc/G8TA-P ${ }_{2} L D$ ] (requiring students to complete the twenty-seven units of the first-year J.D. program)

7x. Master of Science-Legal Studies Program, CoRnell L. SCH. (20I6), http://www.lawschool.cornell. edu/admissions/degrees/master-of-science.cfm [https://perma.cc/Y7V6-NEXC].

72. In 2013, Appalachian School of Law received ABA acquiescence to award a juris master (J.M.) after successful completion of three semesters of the J.D. program. Furis Master Degree, Appalachian SCH. L. (20r6), http://www.asl.edu/J.D.-Program/Juris-Master-Degree.html [https://perma.cc/ $\mathrm{N}_{5} \mathrm{P} 8{ }_{5}$ WCS]. However, enrollment at Appalachian School of Law has declined by almost eighty percent since $201 \mathrm{I}$ and enrolled only thirty-two first-year students in 2015, so this master's option is not likely to be taken up by many students. See Staci Zaretsky, This Law School's Enrollment Is Down by Almost 80 Percent, ABOve THE L. (Aug. 18, 2015), http://abovethelaw.com/2015/08/this-law-schools-enrollment-is-down-by-almost-80percent/Prf=I [https://perma.cc/87 AH-YGKJ]. 
test.73 Because of the limited information about the realities of law school education, entering law school is risky for lower-income students who are less likely than more privileged students to have family members or family friends who are lawyers. It is plausible that those with lower income or lower family educational background refrain from entering law school because of high costs and the lack of a safety net should they not complete their degree. The combination of uncertainty about fit with the legal profession and certainty of high debt (or at least high opportunity costs for those with substantial scholarships) associated with three years of law school makes entering law school a riskier proposition for students from less-advantaged backgrounds. ${ }^{74}$

In fact, law school has become a far riskier venture over the past thirty years as law school tuition has escalated, far outpacing the rate of inflation. ${ }^{75}$ Yet lawyer salaries over this same period have been essentially flat for fulltime jobs except in private practice once inflation is factored in..$^{6}$ The share of law graduates securing high-paying private-sector jobs is low except at the most elite law schools. 7 As commentators have observed, what would have

73. See Paul Campos, Don't Go to Law School (Unless): A Law Professor's Inside Guide to Maximizing Opportunity and Minimizing Risk go (20I2) (advising students to "avoid the sunk cost fallacy, and to be willing to walk away from law school ..."); TAMANAHA, supra note 13 , at 159 ("Any student who enters law school banking on landing a corporate law job will know by the end of the first year whether that is possible . . . Walking away with $\$ 40,000 \mathrm{debt}$ and no law degree beats leaving after two more years of lost earnings with $\$ 120,000$ debt and a job that does not pay the bills.").

74. There is also a relation between race and debt. See WILDER, supra note 5 , at 7 (reporting that among graduates of the class of 2000 , blacks receive fifty-seven percent of their support from loans and nine percent from family, Hispanics receive sixty-six percent from loans and fifteen percent from family, and whites receive forty-eight percent from loans and twenty-one percent from family).

75. Section of Legal Educ. \& Admissions to the Bar, Law School Tuition: 1985-2012, Am. B. Ass'N (20I6), http://www.americanbar.org/content/dam/aba/administrative/legal_education_ and_admissions_to_the_bar/statistics/s_tuition.authcheckdam.pdf [https://perma.cc/ $\mathrm{JM}_{2} \mathrm{E}-\mathrm{KTM}_{3}$ ] (reporting law school tuition for the period 1985 to 20I2). See Standard 509 Information Reports, supra note 44 (reporting the share of students receiving discounted tuition for each ABA-approved law school in 2015).

76. Salary Trends for New Law Graduates-1985-2013, NALP BULL. (Jan. 2015), http://www.nalp. org/oII5research [https://perma.cc/BY 7 S-V 4 RJ].

77. Ronit Dinovitzer, Bryant G. Garth, Richard Sander, Joyce Sterling \& Gita Z. Wilder, After the J.D.: First Results of a National Study of Legal Careers 42 (2004) (Graduates from the most selective law schools work "disproportionately in the larger offices in private practice and in the markets where the highest paid lawyers are located," and, in contrast, those graduating from medium- to low-selectivity schools are more likely to work in "smaller firms, in state and local government, or in the business sector, where salaries tend to be somewhat lower." The highest median annual salary reported is $\$ 150,000$ for practices of over 250 lawyers, which employ thirty-six percent of respondents who graduated from a top-twenty-ranked law school, while only nine percent of graduates from law schools ranked lower than the top twenty report working in a firm larger than $25^{\circ}$ lawyers.). 
been a manageable debt for the typical law graduate thirty years ago is not sustainable with the current high tuition levels. ${ }^{7}$ Faced with these risks, lowerincome prospective students who engage in a benefit-cost analysis may be discouraged from applying to law school.

In contrast to students who do not complete their $\mathrm{Ph} . \mathrm{D}$. but generally still have a master's degree option, law students who do not complete their J.D. degree leave law school without any additional academic credential. The absence of any additional credential for those who successfully complete a substantial part of the law school curriculum but depart before graduation has two negative consequences. These law school leavers have no way to signal on job applications or resumes that they left voluntarily instead of flunking out, and they have no additional credential to provide when seeking employment to indicate that they have additional academic training.

Granting the M.L.P. would provide two distinct advantages to potential students. Students unsure of their fit could enter law school and complete the J.D. if the fit were strong; if it were not, they could earn a master's degree that would allow them to be competitive for jobs for which a master's degree is a valued credential. As the following section documents, knowledge of law and government is important in a wide range of occupations.

\section{B. The Master's Degree Option Expands the Applicant Pool and Allows More Risk-Taking in Admissions}

My proposed master's degree option would allow law schools to admit potentially riskier students without fearing violating ABA accreditation standards on bar passage rates, as those students who found that their fit with the legal profession was weak would leave law school with a master's degree, not a J.D., and would not be counted as J.D. graduates eligible to take the bar exam. 79

This increase in applicants would offset pressures faced by some law schools to admit less-qualified applicants or to increase scholarships to maintain class size and revenue. ${ }^{80}$ Law schools would not fear that they were exploiting students by admitting potentially riskier students because the M.L.P. degree would provide a valuable, standardized market credential for those students

78. The recent downturn in the law market in which a large number of recent J.D. graduates are not employed as lawyers, or not employed full time at all, exacerbates the consequences of incurring high debt while in law school; but the general point that escalating tuition has led to vastly greater debt holds regardless of the demand for lawyers. See TAMANAHA, supra note I3, at 108-25.

79. Recent debate over the $A B A$ 's Standard $3^{1} 6$ raises concerns about the relation between $A B A$ requirements for bar passage rates and the recruitment and admission of minority students. See Robert R. Furnier, Proposed ABA Law School Accreditation Standard 3 I6: A Threat to Diversity in Law Schools and the Legal Profession? LAW PRAC. TODAY (July I4, 2016), http://wwwllawpracticetoday. org/article/hbcu-law-school-accreditation-standard/ [https://perma.cc/KJ84-XN72].

8o. TAMANAHA, supra note 13 , at $160-66$ (describing recent trends showing a decline in law school applications and an increase in acceptance rates and scholarships, leading to a decline in both revenue and student quality at many law schools). 
who chose to leave after completing their IL year. In addition, rather than limit the potential applicant pool to those applying only to law schools, this master's option would increase the applicant pool, as it would be an alternative to other master's degrees that offer preparation for similar occupations, as I document in the following section. ${ }^{8}$

Although the master's degree option may be accompanied by increased attrition after the $\mathrm{rL}$ year, meeting enrollment targets can be done in the same way that enrollment targets are met under the current regime in which there is attrition as students leave law school entirely or transfer between law schools, by accepting transfer students (as currently done), or by increasing the size of their entering $\mathrm{I} L$ class in anticipation of a combination of transfers and those leaving after completing their IL year with a master's degree. ${ }^{82}$

8I. Law schools may also wish to consider accepting the GRE as a substitute for the LSAT. The University of Arizona College of Law began accepting applicants based on either the GRE or LSAT in 2016, and Harvard Law School has announced a pilot program to accept GRE-only applicants for admission beginning in fall 2017. UA Becomes First Lave School to Open Admissions to All GRE Test Takers after Study Reveals Test Validity, U. ARIz. C. L. (Feb. 2, 2016), https://law.arizona.edu/arizona-law-school-gre [https://perma.cc/9757-TUWA]; In Pilot Program, Haruard Law Will Accept GRE for Admission, HaRv. L. TODAY (Mar. 8, 2017), https:// today.law.harvard.edu/gre/ [https://perma.cc/NF 4 B-UMBA]. On August 7, 2017, the law schools at Georgetown and Northwestern announced that they will begin accepting the GRE or LSAT in admissions. Stephanie Francis Ward, Georgetorem Law Says It Will Accept the GRE as an Entrance Test, A.B.A. J., Aug. 7, 2017, http://www.abajournal.com/news/ article/georgetown_law_says_it_will_accept_the_gre_as_an_entrance_test [https:// perma.cc/ $L_{5}$ TW-PHGX]. The GRE can be submitted for application to a broad array of graduate programs including master's programs in business, public policy, and public administration that students may consider as alternatives to the J.D. 2or6-i7 Institutions \& Felloweship Sponsors Approved to Receive GRE Scores, Educ. TESTING SERV. (20I6), https://www.ets. org/s/gre/pdf/gre_aidi_fellowships.pdf [https://perma.cc/UXP8-XY 3 K]. Currently, the LSAT is offered only four times a year at specifically scheduled dates, which introduces both inflexibility and far higher stakes relative to the GRE which can be taken at testing centers on demand. See Test Centers and Dates, Educ. Testing SERv. (20r6), https://www.ets. org/gre/revised_general/register/centers_dates/ [https://perma.cc/gU8H-BQMZ]. Riskaverse potential students will find the expected payoff from the GRE to be higher than from the LSAT, limiting the diversity of potential law school applicants. A key argument in favor of accepting the GRE is to increase applicant diversity. See Sarah Mui, Should Law Schools Accept the GRE as Well as the LSAT? ABA J. (July 6, 2016), http://www.abajournal. com/news/article/should_law_schools_accept_the_gre_as_well_as_the_lsat/?utm_ source=maestro\&utm_medium=email\&utm_campaign=weekly_email [https://perma. $\mathrm{cc} / 38 \mathrm{CZ}-33 \mathrm{AT}$ ] (quoting Catherine Christopher, an assistant professor at Texas Tech University School of Law: "For me, the interesting question is whether accepting the GRE would attract a different pool of applicants-more racially and ethnically diverse or students with different skill sets, experiences or expertise. . . I think communities benefit tremendously when their lawyers and law students reflect the characteristics of the population as a whole.").

82. If attrition becomes higher if the M.L.P. becomes available, law schools are likely to take varying approaches to maintaining enrollment targets for their ${ }_{2} \mathrm{~L}$ and ${ }_{3} \mathrm{~L}$ classes. For example, iL classes may become larger, or law schools may hire extra faculty, including hiring faculty to primarily teach $\mathrm{IL}$ courses. 


\section{Nonlawyer Occupations in Which Legal Knowledge Is Valuable}

\section{A. J.D. Advantage Jobs}

It is often argued that a law degree has value in many occupations, as legal education provides versatile training, and J.D. graduates who are not employed as lawyers will be employed in related fields in which legal knowledge is valued. ${ }^{83}$ The anticipated breadth of occupations requiring legal knowledge is highlighted by the ABA in its employment questionnaire, which includes a category called "J.D. Advantage" jobs. A J.D. Advantage job is defined as follows: "A position in this category is one for which the employer sought an individual with a J.D., and perhaps even required a J.D., or for which the J.D. provided a demonstrable advantage in obtaining or performing the job, but itself does not require bar passage or an active law license or involve practicing law." 84

The ABA lists a number of examples of J.D. Advantage occupations: corporate contracts administrator, alternative dispute resolution specialist, government regulatory analyst, FBI agent, accountant, personnel or human resources professional, compliance worker in business and industry, law firm professional development specialist, journalist, teacher (in a higher education setting) of law and law-related topics, and law school career services officer, admissions officer, or other law school administrative officer. ${ }^{85}$ The ABA also lists jobs in investment banks and consulting firms without indicating which specific occupations within those types of businesses would qualify as J.D. Advantage. ${ }^{86}$ Also listed are "[d]octors or nurses who plan to work in a litigation, insurance, or risk management setting, or as expert witnesses." ${ }_{7}$

\section{B. Identifying Occupations in Which Legal Training Is Valuable Using Government Data}

To systematically identify occupations in which legal knowledge is valuable, but a J.D. is not necessarily required, research assistants working under my supervision searched the Occupational Information Network $\left(\mathrm{O}^{*} \mathrm{NET}\right.$ ) database. ${ }^{88} \mathrm{O}^{*} \mathrm{NET}$ is sponsored by the U.S. Department of

83. Not all observers of the legal market would agree with this view. See CAMPos, supra note 73 , at 28 (titling chapter 5, "The Myth of the Versatile Law Degree").

84. 2016 Employment Questionnaire (For 2015 Graduates): Definitions \& Instructions, Am. B. Ass'N 2-3 (2016), http://www.americanbar.org/content/dam/aba/administrative/legal_education_ and_admissions_to_the_bar/Questionnaires/2016_eq_efinitions_and_instructions. authcheckdam.pdf [https://perma.cc/ $\mathrm{X}_{2} \mathrm{KW}-\mathrm{L}_{7} \mathrm{RA}$ ] [hereinafter Employment Questionnaire].

85. Id., at 2-3.

86. Id., at 2 .

87. See id., at 3 (listing doctors and nurses as other examples of "Professional Positions").

88. O*NET ONLINE (20I6), https://www.onetonline.org/ [https://perma.cc/VGJg-AL7 $\mathrm{S}$ ]. $\mathrm{O}^{*} \mathrm{NET}$ data is used in a number of articles published in the economics literature. See, e.g., 
Labor/Employment and Training Administration and is the primary source of occupational information in the United States. Information is provided both by job holders and by occupational analysts. The $\mathrm{O}^{\star} \mathrm{NET}$ taxonomy currently includes 974 occupations. $\mathrm{O}^{*} \mathrm{NET}$ reports a wealth of highly detailed occupational information for each of these 974 occupations. The O*NET content model is divided into six broad groups (called "domains"); three of these groups focus on characteristics of workers and three focus on characteristics of jobs. The worker-oriented categories are: worker characteristics (abilities, occupational interests, work values, work styles), worker requirements (skills, knowledge, education), and experience requirements (experience and training, entry requirement or licensing). Job-oriented categories are occupational requirements (work activities, organizational context, work context), workforce characteristics (labor market information, occupational outlook), and occupation-specific characteristics (job titles, tasks, tools and technology). Scores are assigned to a number of specific items within each broad category. ${ }^{89}$ For each occupation, $\mathrm{O}^{*} \mathrm{NET}$ also reports median salary and employment.

To identify those occupations in which legal knowledge is important, consideration of occupations was limited to those occupations rated at least 60 out of too in importance of knowledge in "law and government." Knowledge in law and government is defined as "knowledge of laws, legal codes, court procedures, precedents, government regulations, executive orders, agency rules, and the democratic political process," and the importance rating is assigned by occupational analysts. This restriction left rog possible occupations.

The next step was to further limit the list of potential occupations to those classified by $\mathrm{O}^{\star} \mathrm{NET}$ as typically requiring a bachelor's degree or higher. These are the occupations with Job Zone rating of 4 or $5^{.{ }^{\circ}} \mathrm{Job}$ Zone 4 states that most occupations "require a four-year bachelor's degree, but some do not," and the education description for Job Zone 5 states that most occupations require graduate school and that some "may require a master's degree, and some require a Ph.D., M.D., or J.D. (law degree)." Occupations that require

Joni Hersch \& Jean Xiao, Sex, Race, and Job Satisfaction Among Highly Educated Workers, 83 S. Econ. J. I (2016) (examining the relation between working conditions and job satisfaction); Barry T. Hirsch, Why Do Part-Time Workers Earn Less? The Role of Worker and Job Skills, 58 Indus. \& LAB. REL. REv. 525 (2005) (showing that much of the wage gap between full-time and part-time workers is due to occupation skill requirements and working conditions).

89. For an example of the wide range of characteristics that are rated in the $\mathrm{O}^{*} \mathrm{NET}$ content model, see Details Report for: 23-rorr.oo-Lawyers, O*NET (2016), http://www.onetonline.org/ link/details/23-ron.oo [https://perma.cc/UFZg-QSXU] (giving a detailed report of the $\mathrm{O}^{*}$ NET occupation for "Lawyers").

9o. The $\mathrm{O}^{*}$ NET Job Zone ranking system categorizes occupations by the amount of preparation needed to do the work, ranging from Job Zone I (occupations that need little or no preparation) to Job Zone 5 (occupations that need extensive preparation). See $O^{*}$ NET OnLine Help: Job Zones, O*NET (2016), http://www.onetonline.org/help/online/zones [https:// perma.cc/VC. 5 -QG64]. 
less than a bachelor's degree would generally not be considered as J.D. Advantage jobs, nor would they seem to be desirable jobs for those with my proposed master's degree. Furthermore, Job Zone 4 occupations are unlikely to be those in which a J.D. is required or is common. After the restriction to occupations rated 60 or higher in importance of knowledge in law and government and with occupational preparation in Job Zone 4 or 5 , sixty-four individual occupations remained. In the $\mathrm{O}^{*} \mathrm{NET}$ data, some occupations with relatively few employees are combined with similar occupations and are grouped together in the reports of salary and employment. After taking into account grouped occupations, there are fifty-five separate entries; for brevity I will refer to each entry as an "occupation." ${ }^{r}$

Finally, I compared these fifty-five occupations to the examples of J.D. Advantage jobs. Five of these occupations-lawyers, judges, administrative judges, judicial law clerks, and law teachers-would fall into the category of "Employed-Bar Passage Required" in the ABA employment questionnaire.92 An additional twenty-one occupations match up reasonably well with the examples of J.D. Advantage jobs (broadly interpreted). These twenty-six occupations are listed in Table 2, together with median salary, 2014 employment, job zone (either 4 or 5 , given the restriction to occupations that typically require a bachelor's degree or higher), and rating of importance of knowledge of law and government (from 6o to roo, given the restriction to occupations with scores of at least 60 ). The five occupations that typically require bar passage are listed at the top of Table 2, in descending order by 2014 employment, followed by the twenty-one occupations for which a J.D. would provide an advantage, also sorted in descending order by 2014 employment. The remaining twentynine occupations are listed in Appendix I and are included to indicate the range of occupations in which knowledge of law and government is generally valuable for job performance. These occupations would likely be classified in the ABA employment questionnaire as "professional positions." A professional position is defined as "one that requires professional skills or training but for which a J.D. is neither required nor a demonstrable advantage."93 The range of occupations indicated in Appendix I, including occupations as varied as

9r. Although all occupations in a broad grouping are assigned the same salary and employment values in the $O^{\star}$ NET data, not all occupations included in the broad groupings meet the criteria for inclusion in Table 2 . The job zone and importance ratings reported in Table 2 are based on only those occupations that meet the criteria for inclusion.

92. Employment Questionnaire, supra note 84, at 2-3.

93. Id. (listing examples of professional positions: "a math or science teacher, business manager, or performing arts specialist ... professions such as doctors, nurses, engineers, or architects"). As a review of Appendix I below indicates, most of these jobs would require specific training, education, or licensing beyond a law school education. 
engineer and fish and game warden, attests to the value of legal education even among those who pursue nonlegal professions.

\begin{tabular}{|c|c|c|c|c|}
\hline \multicolumn{5}{|c|}{ Table 2. Occupations in Which Legal Knowledge Is Valuable } \\
\hline \multicolumn{5}{|c|}{ Panel A: Legal Occupations Likely Requiring a J.D. } \\
\hline Occupation & $\begin{array}{c}\text { Median } \\
\text { Salary } \\
(2015) \\
\end{array}$ & $\begin{array}{l}\text { Employment } \\
\text { (2014) }\end{array}$ & $\begin{array}{l}\text { Job } \\
\text { Zone }\end{array}$ & $\begin{array}{c}\text { Importance } \\
\text { of Law and } \\
\text { Government }\end{array}$ \\
\hline Lawyers & $\$ 115,820$ & 779,000 & 5 & 93 \\
\hline $\begin{array}{l}\text { Judges, Magistrate Judges, } \\
\text { and Magistrates }\end{array}$ & $\$ 126,93^{\circ}$ & $3^{\circ}, 000$ & 5 & $9^{8}$ \\
\hline Law Teachers, Postsecondary & $\$ 105,250$ & 21,000 & 5 & 100 \\
\hline $\begin{array}{l}\text { Administrative Law Judges, } \\
\text { Adjudicators, and Hearing } \\
\text { Officers }\end{array}$ & $\$ 90,600$ & $\mathrm{r}_{5}, \mathrm{OOO}$ & 5 & $9^{\mathrm{I}}$ \\
\hline Judicial Law Clerks & $\$ 5^{\circ}, 740$ & 12,000 & 5 & 100 \\
\hline \multicolumn{5}{|c|}{ Panel B: Occupations with J.D. Advantage } \\
\hline Occupation & $\begin{array}{l}\text { Median } \\
\text { Salary } \\
(2015)\end{array}$ & $\underset{(2014)}{\text { Employment }}$ & $\begin{array}{l}\text { Job } \\
\text { Zone }\end{array}$ & $\begin{array}{l}\text { Importance } \\
\text { of Law and } \\
\text { Government }\end{array}$ \\
\hline $\begin{array}{l}\text { Compliance and Regulatory } \\
\text { Affairs Managers }\end{array}$ & $\$ \mathrm{IO}_{4}, 8_{5} \mathrm{O}$ & $9^{86,000}$ & 4 & $7^{1-8 I}$ \\
\hline Treasurers and Controllers & $\$ 117,990$ & $55^{6,000}$ & 5 & 63 \\
\hline $\begin{array}{l}\text { Preventive Medicine } \\
\text { Physicians }\end{array}$ & $\$ 187,200+$ & 347,000 & 5 & $7^{2}$ \\
\hline $\begin{array}{l}\text { Medical and Health Services } \\
\text { Managers }\end{array}$ & $\$ 94,5^{\circ 0}$ & 333,000 & 5 & 63 \\
\hline Compliance Officers & $\$ 6_{5}, 640$ & 260,000 & 4 & $79-86$ \\
\hline $\begin{array}{l}\text { Fraud Examiners, Investiga- } \\
\text { tors, and Analysts }\end{array}$ & $\$ 66,670$ & 145,000 & 4 & 86 \\
\hline Human Resources Managers & $\$ \mathrm{IO} 4,440$ & 123,000 & 4 & 66 \\
\hline Intelligence Analysts & $\$ 77,2$ IO & 117,000 & 4 & 82 \\
\hline $\begin{array}{l}\text { Environmental Scientists and } \\
\text { Specialists, Including Health }\end{array}$ & $\$ 67,46 \mathrm{o}$ & 95,000 & $4-5$ & $66-8 o$ \\
\hline $\begin{array}{l}\text { Probation Officers and } \\
\text { Correctional Treatment } \\
\text { Specialists }\end{array}$ & $\$ 49,3^{60}$ & $9^{2,000}$ & 4 & $8_{3}$ \\
\hline Labor Relations Specialists & $\$ 58,820$ & 82,000 & 4 & 74 \\
\hline $\begin{array}{l}\text { Occupational Health and } \\
\text { Safety Specialists }\end{array}$ & $\$ 70,2$ IO & 70,000 & 4 & 75 \\
\hline Budget Analysts & $\$ 71,590$ & 61,000 & 4 & 64 \\
\hline $\begin{array}{l}\text { Reporters and } \\
\text { Correspondents }\end{array}$ & $\$ 3^{6,360}$ & 49,000 & 4 & 74 \\
\hline
\end{tabular}




\begin{tabular}{|c|c|c|c|c|}
\hline \multicolumn{5}{|c|}{ Table 2. Occupations in Which Legal Knowledge Is Valuable } \\
\hline \multicolumn{5}{|c|}{ Panel B: Occupations with J.D. Advantage } \\
\hline Occupation & $\begin{array}{l}\text { Median } \\
\text { Salary } \\
\text { (2015) }\end{array}$ & $\begin{array}{l}\text { Employment } \\
\text { (2014) }\end{array}$ & $\begin{array}{l}\text { Job } \\
\text { Zone }\end{array}$ & $\begin{array}{l}\text { Importance } \\
\text { of Law and } \\
\text { Government }\end{array}$ \\
\hline Financial Examiners & $\$ 78$,ого & 38,000 & 4 & 65 \\
\hline $\begin{array}{l}\text { Urban and Regional } \\
\text { Planners }\end{array}$ & $\$ 68,220$ & 38,000 & 5 & 79 \\
\hline Transportation Planners & $\$ 76,38$ o & $3^{6,000}$ & 4 & 75 \\
\hline $\begin{array}{l}\text { Environmental Science and } \\
\text { Protection Technicians, } \\
\text { Including Health }\end{array}$ & $\$ 43,030$ & $3^{6,000}$ & 4 & 68 \\
\hline $\begin{array}{l}\text { City and Regional Planning } \\
\text { Aides }\end{array}$ & $\$ 42,480$ & 32,000 & 4 & 78 \\
\hline $\begin{array}{l}\text { Criminal Justice and Law } \\
\text { Enforcement Teachers, } \\
\text { Postsecondary }\end{array}$ & $\$ 5^{8}, 77^{\circ}$ & 17,000 & 5 & 90 \\
\hline $\begin{array}{l}\text { Arbitrators, Mediators, and } \\
\text { Conciliators }\end{array}$ & $\$ 58,020$ & 8,000 & 5 & 68 \\
\hline
\end{tabular}

\section{The Master in Legal Principles is Sufficient for Most F.D. Advantage Jobs}

As Table 2 demonstrates, a number of nonlawyer occupations would be considered by the ABA to be J.D. Advantage occupations. But few of these nonlawyer occupations have salary or employment levels that compare favorably to median lawyer salary and employment levels. For reference, median lawyer salary is $\$ I_{15}, 820$ and 2014 employment is 779,000 .

Excluding preventive medicine physicians, ${ }^{94}$ who have the highest median pay but would require an M.D. and a plan to work in a litigation, insurance, or risk-management setting, or as expert witnesses in order to be considered J.D. Advantage, 95 only three occupations compare favorably in salary and employment with lawyers. One is "treasurers and controllers," and, while a J.D. may provide an advantage, the usual training for this job would be accounting and other financial training, and not a J.D. More feasible would be the grouping of managers labeled "compliance and regulatory affairs managers," 96 with median salary of $\$ 104,850$ and employment of 986,000 , and "human resources managers," with median salary of $\$ 104,440$ and employment

94. O*NET reports data for "physicians and surgeons, all other" for preventive medicine physicians.

95. No doctor or nurse occupations other than preventive medicine physicians had an importance of knowledge of law and government rating of 60 or higher, so no other doctor or nurse occupations appear in either Table 2 or Appendix I.

96. In the $\mathrm{O}^{*}$ NET data, this grouping is called "managers, all other," and includes a group of nine occupations. Five occupations-brownfield redevelopment specialists and site managers, loss prevention managers, regulatory affairs managers, security managers, and compliance managers-met the criteria for inclusion in Table 2. 
of I23,000. Both of these occupations are classified as Job Zone 4, meaning that most jobs in these occupations would not require education beyond a bachelor's degree, and therefore would not require a J.D. Compliance work is also considered to be a J.D. Advantage job, but as indicated in Table 2, the median pay of compliance officers ${ }^{97}$ of $\$ 65,640$ is well below the median pay of lawyers, and also is in Job Zone 4 , indicating a J.D. is unnecessary..$^{8}$

A requirement for a job to be "J.D. Advantage" is that a J.D. is not uncommon among holders of these positions. 99 Notably, a J.D. would in fact be uncommon, or at least unnecessary, for most of the occupations listed in Table 2, because most of these occupations fall into Job Zone 4. That a J.D. is not required or common for most jobs indicated by the ABA as J.D. Advantage jobs, or for many other occupations for which knowledge in law and government is valuable, at least hints that those with a J.D. who are not employed as lawyers likely did not need a full three-year program to attain that knowledge.

For potential law students deciding whether law school is a financially sound decision, if the employment outcome is not sufficiently improved by earning a J.D. and passing the bar relative to earning my proposed one-year M.L.P. degree, the direct and opportunity costs associated with three years of law school suggest an inferior financial outcome relative to a one-year master's degree. Indeed, students with the M.L.P. degree might end up with a better return on their investment in education than they would from a J.D. under many plausible assumptions related to the actual earnings of lawyers, cost of borrowing, and opportunity cost of an additional two years of graduate education.

\section{Limited Legal Licensing}

\section{A. Nonlaweyer Provision of Legal Services to Bridge Access-to-Justice Gap}

Studies indicate that a large share of the U.S. population does not have adequate access to legal services because of the cost. ${ }^{100}$ As a means of addressing this access-to-justice gap, legal scholars have called for innovations

97. The grouping of compliance officers includes six occupations. Three of these occupations met the criteria for inclusion in Table 2-equal opportunity representatives and officers, regulatory affairs specialists, and environmental compliance inspectors.

98. The remaining grouped occupation reported in Table 2 is environmental scientists and specialists, including health. This group includes climate change analysts and environmental restoration planners.

99. Employment Questionnaire, supra note 84 , at 3 ("It is an indicator that a position does not fall into this category [J.D. Advantage] if a J.D. is uncommon among persons holding such a position.").

roo. Legal Servs. Corp., supra note 2. 
to allow more options in provision of legal services. ${ }^{101}$ The $\mathrm{ABA}^{102}$ and a number of states either allow or are considering proposals to allow nonlawyers to offer limited legal services. ${ }^{\mathrm{ro3}}$ The Washington State Bar Association has recently approved granting a limited license to nonlawyers. ${ }^{104}$ The state bars of Oregon ${ }^{105}$ and California ${ }^{106}$ have convened task forces and have issued reports that recommend consideration of limited licensing similar to Washington. New York is piloting having nonlawyers, referred to as "navigators," help unrepresented litigants in housing and consumer-debt cases. ${ }^{107}$

The ABA Report on the Future of Legal Services in the United States describes "[a] growing number of U.S. jurisdictions that have authorized Legal Services Providers (LSPs) other than lawyers to help address the unmet needs for legal services ...." "108 These LSPs include federal agencies (Department of Justice, Department of Homeland Security, Equal Employment Opportunity Commission, Internal Revenue Service, Patent and Trademark Office, and

10r. See Gillian K. Hadfield, The Cost of Law: Promoting Access to fustice Through the (Un) Corporate Practice of Law, $3^{8}$ INT'L REV. L. \& ECON. 1, 17 (2OI3) (recommending eliminating restrictions on the corporate practice of law); Gillian K. Hadfield, Innovating to Improve Access: Changing the Way Courts Regulate Legal Markets, I43 DaEdalus 5 (2014) (describing lack of meaningful access to legal assistance faced by many Americans and the role of excessive restrictions on legal markets in limiting access to justice); Elizabeth Chambliss, Renee Newman Knake \& Robert L. Nelson, Introduction: What We Know and Need to Know About "Access to Fustice" Research, 67 S.C. L. REv. 193, I93 (2016) (introduction to a symposium issue with sixteen white papers on various aspects of access to justice).

102. Am. Bar Ass'n, Report on the Future of Legal Services in the United States (2016), http://www.americanbar.org/content/dam/aba/images/abanews/20r6FLSReport_FNL_ WEB.pdf [https://perma.cc/7SQT-6LFY] [hereinafter FuTURE OF LEGAL SERVICES]

I03. See Elizabeth Chambliss, Law School Training for Licensed "Legal Technicians"? Implications for the Consumer Market, 65 S.C. L. REv. 579, 580 (2014) (describing limited licensing and the potential role of law schools in standardizing training). See also Robert Ambrogi, Washington State Moves Around UPL, Using Legal Technicians to Help Close the Justice Gap, ABA J. (Jan. I, 20I5), http://www.abajournal.com/magazine/article/washington_state_moves_around_upl_ using_legal_technicians_to_help_close_the [https://perma.cc/XRR6-WRQN].

104. Limited License Legal Technician Program, Wash. State Bar Ass'n (20I6), http://www.wsba. org/licensing-and-lawyer-conduct/limited-licenses/legal-technicians [https://perma.cc/ $\mathrm{SL} 84-95 \mathrm{~V} 8]$.

i05. Legal Technicians Task Force, Final Report to the Board of Governors (Feb. i3, 2015), http://bogir.homestead.com/LegalTechTF/Jan20I5/Report_22Jan2015.pdf [https:// perma.cc/BgKR-gTGN].

ro6. State Bar of Cal. Task Force on Admissions Regulation Reform: Phase I Final RePORT (20I3), http://www.calbar.ca.gov/Portals/o/documents/bog/ bot_ExecDir/ADA\%2oVersion_STATE_BAR_TASK_FORCE_REPORT_(FINAL_ AS_APPROVED_6_II_13)_o624I3.pdf [https://perma.cc/C2FM-6V8L].

107. Comm. on Prof. Resp., N.Y.C. Bar Ass'n, Narrowing the "Justice Gap": Roles for Nonlawyer Practitioners (2013), http://www2.nycbar.org/pdf/report/uploads/20072450RolesforNonlawyerPractitioners.pdf [https://perma.cc/F3AG-WgV6].

108. Future OF LeGAL Services, supra note IO2, at t9-24. 
Social Security Administration), courthouse navigators (New York, Arizona), courthouse facilitators (California, Washington State), limited practice officers (Washington State), and document preparers (Arizona, California, Nevada). The rationale for limited licensing and provision of legal services by nonlawyers is stated explicitly as a means of expanding access to justice. ${ }^{109}$

The licensing arrangement in Washington is instructive, as it is currently the only state that licenses nonlawyers to provide limited legal services. A nonlawyer in Washington who meets the requirements and passes the legal technician exam may provide legal services as a limited license legal technician (LLLT). An LLLT may "consult and advise, complete and file necessary court documents, help with court scheduling and support a client in navigating the often confusing maze of the legal system." fairly low, requiring only an associate degree. Applicants for the LLLT must complete forty-five credit-hours of a core legal curriculum, complete courses in the practice area in which they seek to be licensed, and have 3,000 hours of substantive law-related work experience supervised by a licensed lawyer. Currently, family law is the only practice area licensed. The Oregon task force likewise recommends that any licensing of nonlawyers be restricted to limited areas, specifically family law, landlord/tenant law and small-claims advising."'

\section{B. Relation of Master of Legal Principles to Licensing Criteria}

Those who have completed a $\mathrm{IL}$ year would likely meet most of the educational requirements for a limited legal license in Washington. In fact, the core curriculum in Washington overlaps with the standard IL curriculum, although because the required educational background for the LLLT is an associate degree and not a bachelor's degree as for J.D. candidates, the level of instruction is expected to be lower. The core curriculum in Washington covers topics such as civil procedure, contracts, legal research and writing, and professional responsibility, as well as topics not in a standard $\mathrm{IL}$ curriculum such as law office procedures and technology. Thus, states that license nonlawyers for provision of some legal services may be willing to accept the M.L.P. in fulfillment of their requirements for a limited legal license.

While the state's task forces take a narrow view of the practice areas covered by or proposed for limited licensing, concerns over access to justice and lack of representation in underserved communities (such as rural areas) ${ }^{112}$ may lead states to increase the scope of legal services that can be provided by

Iog. See, e.g., Limited License Legal Technician Program, supra note ro4. See also LeGaL Technicians Task FORCE, supra note 105, at 3 (stating that the "primary concern of the Task Force was the issue of access to justice").

п1о. Limited License Legal Technician Program, supra note 104.

III. Legal TeChnicians TASK Force, supra note I05, at 40-43.

in2. Ill. State Bar Ass'n, Special Comm. on the Impact of Law Sch. Debt on the Delivery of Legal Servs., Final Report \& Recommendations (2013), http://www.americanbar.

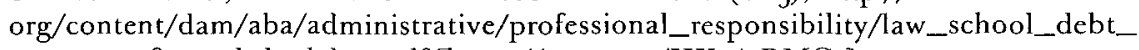
report_030813.authcheckdam.pdf [https://perma.cc/HK2A-RMC 3 ]. 
nonlawyers who would have considerable training, which would be provided by my proposed M.L.P. degree. This parallels the expansion in health care services provided by nurse practitioners and physician assistants. ${ }^{13}$ Even if the scope of legal services provision is not greater for those with the M.L.P., as with other professional services, potential clients may be willing to pay higher fees to a practitioner with a master's degree than to one who does not have a master's degree. For example, paid tax return preparers have a wide range of academic preparation, ${ }^{14}$ and the price of tax preparation accordingly differs by type of practitioner.

\section{Conclusion}

What would law schools, the economy, and the justice system look like if law schools offered my proposed master of legal principles degree for those who successfully complete their IL year of a J.D. program?

The immediate impact on law schools would be to increase the number and diversity of applicants, which would assist in revitalizing legal education. Those who currently apply to law schools to obtain a J.D. would be no less likely to apply simply because another degree option had become available: Adding an additional degree option would not make law school less attractive to those seeking a J.D. However, the additional option would be a plus for potential law students deterred from law school because of the costs and uncertainty about their fit. This new degree option would provide an opportunity to experiment with the fallback option of a valuable master's degree. This fallback option would be of particular value to potential students from lowerincome and diverse backgrounds, as these are the students for whom costs are a barrier and knowledge about their fit with the legal profession is limited. Potential students considering other professional master's programs that are shorter in duration than the J.D. program, such as public policy or business administration, could now include law school as one of the options.

Individual law schools will vary in whether or not they offer a master of legal principles degree, and will also vary in how much attrition they experience when the master's degree option is available. Law schools would be able to take more risks in admissions, which would also enhance diversity of the

II3. See John K. Iglehart, Meeting the Demand for Primary Care: Nurse Practitioners, NAT'L INST. FOR Health Care MGM'T. (Oct. 2014), http://www.aacn.nche.edu/downloads/aacn-future-taskforce/Inglehart-PC-Article.pdf [https://perma.cc/5WSD-96gN] (Nurse practitioners have increased access to primary care.). The Role of Physician Assistanis in Health Care Delivery, NAT'L GOVERNOR's Ass'N (Sept. 22, 20I4), http://www.nga.org/files/live/sites/NGA/files/pdf/2o I4/I4ogTheRoleOfPhysicianAssistants.pdf [https://perma.cc/58WP-MQNQ] (Physician assistants deliver health care at lower costs and increase the efficiency of the health care system.).

Ix4. For a description of the types of licensed tax professionals, see Understanding Tax Return Preparer Credentials and Qualifications, IRS (Feb. 23, 2017), https://www.irs.gov/tax-professionals/ understanding-tax-return-preparer-credentials-and-qualifications [https://perma.cc/ $\mathrm{M}_{3} \mathrm{XB}-\mathrm{GJUG}$ ] (stating that "tax professionals have differing levels of skills, education and expertise"). 
student body. Those highly ranked law schools that currently have very low attrition would likely continue to have low attrition, as the expected benefits from completion of the J.D. at these highly ranked law schools clearly exceed the costs. Attrition might increase at some law schools, but in contrast to the current situation in which those law school leavers exit without an additional credential of any kind, students would instead earn a master's degree that confers a credential of legal knowledge.

The economy would benefit from having a broader segment of society with specialized legal knowledge. Conceptualizing the payoff of legal education only as a J.D.-educated lawyer is far too limited. A broad range of occupations requires legal knowledge, but not a J.D., as a job component. Individuals with the master of legal principles degree would benefit from putting their legal training to productive use in the workforce. But society would benefit as well from a workforce more knowledgeable about the legal system. Because such knowledge is highly valuable in the regulatory and legal environment, that in turn would enhance productivity. This potential societal role of law school training is not currently available.

Access to justice and the efficiency of the court system would also benefit from broader legal training. Limited licensing is one option, and legal representation could be provided at lower costs by those with the M.L.P. But even without specifically providing legal services, legal training is valuable to individuals as they and their families and friends navigate such routine matters in their daily lives as home purchases, divorces, and employment contracts.

My proposed master of legal principles degree would provide a mechanism for law schools to broaden the societal role of legal education. Awarding a master's degree to those who successfully complete their IL year of a J.D. program, in the same way that a master's degree is awarded to those who successfully complete core requirements of their Ph.D. program, would broaden the reach of legal education, increase diversity of the law school student body and the legal profession, add value to a wide range of occupations in which legal knowledge is valuable, and advance access to justice. 


\section{Appendix r: Professional Occupations in Which Legal Knowledge Is Valuable}

\begin{tabular}{|c|c|c|c|c|}
\hline Occupation & $\begin{array}{c}\text { Median } \\
\text { Salary } \\
(2015) \\
\end{array}$ & $\begin{array}{l}\text { Employment } \\
\text { (2014) }\end{array}$ & $\begin{array}{l}\text { Job } \\
\text { Zone }\end{array}$ & $\begin{array}{l}\text { Importance } \\
\text { of Law and } \\
\text { Government }\end{array}$ \\
\hline Chief Executives & $\$$ I 75, IIO $_{1}$ & 343,000 & 5 & 73 \\
\hline Purchasing Managers & $\$ 108, \mathrm{I} 20$ & 73,000 & 4 & 66 \\
\hline Political Scientists & $\$ 99,73^{\circ}$ & 6,000 & 5 & 94 \\
\hline Environmental Economists & $\$ 99,180$ & 22,000 & 5 & 63 \\
\hline $\begin{array}{l}\text { Mining and Geological Engineers, } \\
\text { Including Mining Safety Engineers }\end{array}$ & $\$ 94,040$ & 8,000 & 4 & 67 \\
\hline $\begin{array}{l}\text { Education Administrators, } \\
\text { Elementary and Secondary School }\end{array}$ & $\$ 90,410$ & 240,000 & 5 & $6_{5}$ \\
\hline $\begin{array}{l}\text { Product and Industrial Health and } \\
\text { Safety Engineers }\end{array}$ & $\$ 84,600$ & 25,000 & 4 & $69-75$ \\
\hline Environmental Engineers & $\$ 84,560$ & 55,000 & 5 & 78 \\
\hline Civil Engineers & $\$ 82,220$ & $28 \mathrm{I}, 000$ & 4 & 60 \\
\hline Hydrologists & $\$ 79,55^{\circ}$ & 7,000 & 4 & 60 \\
\hline $\begin{array}{l}\text { Political Science Teachers, } \\
\text { Postsecondary }\end{array}$ & $\$ 76,37^{\circ}$ & 22,000 & 5 & $9^{2}$ \\
\hline $\begin{array}{l}\text { Architects, Except Landscape and } \\
\text { Naval }\end{array}$ & $\$ 76, \mathrm{IOO}$ & $\mathrm{II} 3, \mathrm{OOO}$ & 4 & 64 \\
\hline $\begin{array}{l}\text { Area, Ethnic, and Cultural Studies } \\
\text { Teachers, Postsecondary }\end{array}$ & $\$ 7^{2}, 300$ & 12,000 & 5 & 63 \\
\hline History Teachers, Postsecondary & $\$ 69,400$ & 29,000 & 5 & 67 \\
\hline Business Continuity Planners & $\$ 68, \mathbf{1} 70$ & 998,000 & 4 & 62 \\
\hline Emergency Management Directors & $\$ 67,33^{\circ}$ & II,OOO & 4 & 88 \\
\hline Landscape Architects & $\$ 6_{3}, 8$ ro & 23,000 & 4 & 65 \\
\hline $\begin{array}{l}\text { Social Work Teachers, } \\
\text { Postsecondary }\end{array}$ & $\$ 63,390$ & 14,000 & 5 & 64 \\
\hline $\begin{array}{l}\text { Claims Examiners, Property and } \\
\text { Casualty Insurance }\end{array}$ & $\$ 62,980$ & 300,000 & 4 & 69 \\
\hline $\begin{array}{l}\text { Purchasing Agents, Except Whole- } \\
\text { sale, Retail, and Farm Products }\end{array}$ & $\$ 62,220$ & 301,000 & 4 & 69 \\
\hline $\begin{array}{l}\text { Conservation Scientists and Range } \\
\text { Managers }\end{array}$ & $\$ 6 \mathrm{I}, \mathrm{IIO}$ & 21,000 & 4 & 70 \\
\hline Foresters & $\$ 58,230$ & 16,000 & 4 & 68 \\
\hline Surveyors & $\$ 58,020$ & 44,000 & 4 & 83 \\
\hline $\begin{array}{l}\text { Property, Real Estate, and Com- } \\
\text { munity Association Managers }\end{array}$ & $\$ 55,380$ & 314,000 & 4 & 64 \\
\hline $\begin{array}{l}\text { Adapted Physical Education } \\
\text { Specialists }\end{array}$ & $\$ 53,920$ & 40,000 & 4 & 65 \\
\hline
\end{tabular}




\begin{tabular}{|l|c|c|c|c|}
\hline \multicolumn{1}{|c|}{ Occupation } & $\begin{array}{c}\text { Median } \\
\text { Salary } \\
(\mathbf{2 0 1 5})\end{array}$ & $\begin{array}{c}\text { Employment } \\
(\mathbf{2 0 1 4})\end{array}$ & $\begin{array}{c}\text { Job } \\
\text { Zone }\end{array}$ & $\begin{array}{c}\text { Importance } \\
\text { of Law and } \\
\text { Government }\end{array}$ \\
\hline Fish and Game Wardens & $\$ 52,780$ & 6,000 & 4 & 90 \\
\hline Interpreters and Translators & $\$ 44,190$ & 61,000 & 4 & 62 \\
\hline Loan (Credit) Counselors & $\$ 43,840$ & 33,000 & 4 & $6 \mathbf{r}$ \\
\hline $\begin{array}{l}\text { Patient (Customer Service) } \\
\text { Representatives }\end{array}$ & $\$ 31,720$ & $2,582,000$ & 4 & 67 \\
\hline
\end{tabular}

